\title{
EL ESCULTOR FERNANDO DEL CID. ALGUNOS DATOS SOBRE SU VIDA Y SU ACTIVIDAD ARTÍSTICA*
}

\author{
POR \\ JESÚs ÁNGEL SÁNCHEZ RIVERA \\ Universidad Complutense de Madrid
}

El presente artículo pretende esbozar el perfil de un escultor prácticamente desconocido, Fernando del Cid, que habría de desarrollar su actividad durante la segunda mitad del siglo XVIII en Madrid, proyectándola a otros lugares de España. En él incluimos un exiguo catálogo de obras, más de la mitad de ellas atribuidas ahora, con las debidas reservas.

Palabras clave: Fernando del Cid; Escultura. Real Academia de Bellas Artes de San Fernando; Madrid; Iglesia de San Salvador; Talavera de la Reina; Siglo XVIII.

\section{THE SCULPTOR FERNANDO DEL CID. INFORMATION ON HIS LIFE AND ARTISTIC ACTIVITIES}

The author attempts to outline the profile of a practically unknown sculptor, Fernando del Cid, who worked in Madrid during second half of the $18^{\text {th }}$ century, as well as in other places in Spain. He includes a minimal catalogue of the artist's works, over half of them newly attributed, with certain reservations.

Key words: Fernando del Cid; Sculpture; Royal Academy of Fine Arts of Saint Ferdinand; Madrid; Saint Salvador's church; Talavera de la Reina; 18th Century.

Se ha señalado en numerosas ocasiones la necesidad de estudiar la amplia nómina de escultores que durante el siglo XVIII trabajaron en la Villa y Corte de Madrid, donde se desarrolló una fecunda actividad en torno a las obras reales y a los diversos encargos provenientes del ámbito eclesiástico, a lo que se ha de sumar el importante papel, rector y polarizador de las Bellas Artes, ejercido por la Real Academia de San Fernando a partir de mediados de la centuria. En los últimos años la bibliografía sobre este asunto ha crecido considerablemente, pero aún son muchos los nombres que permanecen en el anonimato.

${ }^{*}$ Hemos de agradecer al profesor Francisco J. Portela Sandoval su interés y sus orientaciones en la redacción de este artículo. 
Por tal motivo presentamos este trabajo, que pretende esbozar el perfil de un escultor prácticamente desconocido, Fernando del Cid, que habría de desarrollar su actividad durante la segunda mitad del siglo XVIII en Madrid, proyectándola a otros lugares de España. En él incluimos un exiguo catálogo de obras -más de la mitad de ellas atribuidas ahora, con las debidas reservas-; un catálogo provisional que esperamos se vaya ampliando en el futuro.

La primera noticia que tenemos del escultor es del 29 de junio de 1753, día en que presentó en la Casa de la Panadería de Madrid para conocer las condiciones del Premio de Escultura de Primera Clase de la Real Academia de Bellas Artes de San Fernando que se celebraría ese año -el primero organizado desde su fundación, el 12 de abril de 1752-. Al premio también se presentaron Juan de León, Manuel Álvarez, Pedro Michel y Antonio Valeriano Moyano․․ El asunto que se encargó a los aspirantes para la prueba "de pensado" fue "El desembarco de Colón en Santa Fee, quando plantó la Cruz, y su exaltación"”; la obra en cuestión había de entregarse antes del mes de diciembre de ese año ${ }^{3}$. El día 19 de diciembre tuvo lugar el segundo examen de este premio de escultura, la llamada prueba "de repente", donde se valoraba la capacidad de los concursantes para ejecutar una obra en el mismo día, ya sin la posibilidad de una fraudulenta ayuda ${ }^{4}$; el asunto elegido en este caso fue Augusto, Marco Antonio y Lépido repartiéndose el Imperio Romano. Finalmente, ganó el concurso el francés Pedro Michel, con nueve votos; Manuel Álvarez, natural de Salamanca, obtuvo el segundo premio ${ }^{5}$.

La documentación revela que la política de la Academia era favorecer a los alumnos vinculados a esta institución, en particular a quienes habían realizado mayores progresos en su formación a lo largo del año. De hecho, los cuatro premiados en 1753 en la categoría de escultura de Primera y Segunda Clase eran los únicos -salvo una excepción- que ya habían pasado a la Sala del Natural, donde se copiaban modelos vivos ${ }^{6}$. Asimismo, ha de apuntarse que los opositores

1 También había firmado en junio Juan Porcel, aunque finalmente no se presentaría a la prueba; Archivo de la Real Academia de Bellas Artes de San Fernando [en adelante AASF], Premios (1752-1753), sig. 2-1-1, sin foliar. Para la transcripción de los textos antiguos aquí recogidos se ha mantenido la grafía original de los escritos excepto en las reglas de puntuación y acentuación, donde se han observado las normas actuales, y en el uso de abreviaturas, que han sido desarrolladas. Las letras que van entre corchetes son aclaraciones al texto, mientras que las que van entre paréntesis son las abreviadas; los tres puntos entre paréntesis indican nuestra deliberada omisión de una parte del mismo. El cambio de folio se expresa mediante doble barra oblicua.

${ }^{2}$ Los diferentes asuntos de cada uno los premios -tres por cada una de las tres nobles artes, y cada uno de ellos con medallas de oro y plata- fueron aprobados por don José de Carvajal y Lancaster, primer ministro de Fernando VI, el 27 de junio de ese mismo año en Aranjuez; AASF, Premios (1752-1753), sig. 2-1-1, sin foliar. También está documentado en el AASF, Premios (1753-1772), sig. 2-2-1, sin foliar; Juntas Particulares, Ordinarias, Generales y Públicas (1753-1757), sig. 81-3, fol. 8 r.

3 Únicamente parece haberse conservado la obra de M. Álvarez (Real Academia de San Fernando), que quedó segundo en el certamen; vid. Azcue BreA, Leticia: La escultura en la Real Academia de Bellas Artes de San Fernando. Catálogo y Estudio, Madrid, Real Academia de Bellas Artes de San Fernando, 1994, pp. 141-142, cat. E-145.

${ }^{4}$ Sirva como ejemplo de las irregularidades que a veces se producían el caso de un opositor, Juan Gendres, que en junio de 1769 acusó a otro llamado Dámaso Santos de haber hecho su dibujo fuera de las dos horas nocturnas permitidas "por el peligro de que otro pudiese verlo y corregirlo", aunque en esta ocasión se trataba de la oposición a uno de los premios mensuales de la Academia; AASF, Premios mensuales (1768-1783), sig. 2-5-1, sin foliar.

${ }^{5}$ El ganador del primer premio obtenía una medalla de oro de tres onzas; el premio del segundo también era una medalla de oro, en este caso de dos onzas; AASF, Juntas Particulares, Ordinarias, Generales y Públicas (1753-1757), sig. 81-3, fols. 10 v.-11 r. y 11 v.-16 r.; Premios (1753-1772), sig. 2-2-1, sin foliar.

${ }^{6}$ Como hemos dicho, Michel y Álvarez ganaron las medallas de oro y plata, respectivamente, del Premio de Primera Clase; Isidro Carnicero y Carlos de Salas obtuvieron las de Segunda Clase. Hay que exceptuar a Francisco de Voge -o de Vogue-, que también estaba en la Sala de Natural, y que no logró premio alguno para esta Segunda Clase -eran sólo dos medallas y tres los aspirantes de la citada Sala-; sin embargo, Vogue ganaría al año siguiente dicho premio; AASF, Premios (1753-1772), sig. 2-2-1, sin foliar. 
presentados junto a Del Cid tenían, a priori, una posición más ventajosa que la de nuestro escultor: Juan de León y Manuel Álvarez trabajaban desde hacía tiempo en las obras del Palacio Real Nuevo junto a los académicos que habían de juzgar sus obras; el hermano de Pedro Michel, Roberto, también había trabajado en el Palacio Real, y era Académico de Mérito -o Profesor-y Teniente Director de Escultura -o Director Adjunto- en aquella institución desde su fundación el año anterior ${ }^{7}$; y el presbítero Antonio Valeriano Moyano, de mayor edad, incluso sustituiría a Juan Pascual de Mena en su cargo como Teniente Director de Escultura al año siguiente ${ }^{8}$.

No hemos encontrado el nombre de Del Cid entre los alumnos de la Academia durante esos años. Su nombre tampoco figura entre los aspirantes a los premios anuales posteriores ${ }^{9}$. Por estas razones pensamos que se hubo de formar fuera del ámbito de la Academia, y que sólo se habría presentado al concurso de 1753. Tal vez ejerciera ya como escultor y acudiera al certamen para probar suerte. Sin embargo, como veremos al analizar sus obras, su particular estilo delata el influjo del trabajo de Juan Pascual de Mena (1707-1784), cuyo ejercicio como profesor de escultura de la Academia fructificó en la existencia de numerosos discípulos y seguidores suyos ${ }^{10}$.

${ }^{7}$ De hecho, podemos imaginar las suspicacias que pudieron surgir tras la concesión de estos premios pues, como hemos dicho, aquél de Primera Clase de Escultura fue otorgado a Pedro Michel, cuyo hermano estaba en el tribunal.

${ }^{8}$ Recogen la actividad de estos escultores en el Palacio Real Plaza SANTIAGo, Francisco Javier de la: Investigaciones sobre el Palacio Real Nuevo de Madrid, Valladolid, Universidad de Valladolid, 1975; y TÁrRAGa BALdó, María Luisa: Giovan Domenico Olivieri y el taller de escultura del Palacio Real, 3 vols., vol. II, Madrid, Patrimonio NacionalCSIC-Instituto Italiano de Cultura, 1992.

9 Sólo hemos hallado a un "Joseph Zid, Nat(ura)l de Madrid. Edad 15 a(ño)s", que firma como opositor al Premio de Pintura de Tercera Clase en 1754; AASF, Premios (1753-1772), sig. 2-1-2, sin foliar. ¿Podría tratarse del hijo u otro familiar de nuestro escultor? Aún no podemos aventurar nada.

${ }^{10}$ Así lo explica Ceán en su Diccionario: "[Pascual de Mena trabajó en la Academia] concurriendo con el mayor tesón y zelo a la enseñanza de los jóvenes desde los estudios de la junta preparatoria hasta los últimos meses de su vida, que finalizó en Madrid el día 16 de abril de 1784 con gran sentimiento de sus discípulos, que amaba como a hijos"; CEÁN BERMúdeZ, Juan Agustín: Diccionario histórico de los más ilustres profesores de las Bellas Artes en España, tomo III, Madrid, Viuda de Ibarra, 1800, p. 105 (edición facsímil, con prólogo de Miguel Morán TuRINA: Madrid, Istmo, 2001). Tampoco hay que perder de vista los cargos que ostentó Pascual de Mena, además del de Académico de Mérito, en esta institución: Teniente Director de la Sección de Escultura (1752-1762, ausentado entre 1754 y 1756 por su estancia en Bilbao), Director de Escultura (1762-1784) y Director General (1771-1774). Para conocer los cargos y el funcionamiento de la Academia en relación con los escultores remitimos al trabajo de AzcuE BrEA, Leticia: Op. cit., pp. 1-9.

Uno de los discípulos fue Joaquín Arali Solanas, cuyo paso por la Academia está documentado de la manera siguiente: "escultor e individuo que fue de la Real Sociedad Aragonesa, fue natural de Zaragoza, en donde tuvo sus principios con el escultor Don Manuel Ramírez; siendo joven aún vino a Madrid y travajó mucho tiempo con su segundo maestro, D[on] Juan de Mena, hasta que el año de 1780 regresó a su patria (...)"; AASF, Académicos: necrológicas (s. XVIII), sig. 1-47-1, sin foliar. José Arias, también José Rodríguez Díaz y Manuel Tolsá fueron alumnos suyos, quedando documentada su participación en la Fuente de Neptuno bajo la dirección de Pascual de Mena; vid. PÉREZ DE Domingo, Lorenzo: "La obra del escultor Juan Pascual de Mena en Madrid", Revista de arte, geografia e historia, n. ${ }^{\circ} 8$ (2006), pp. 320 y 322. Otro discípulo del escultor toledano fue Cristóbal Salesa, natural de la localidad aragonesa de Borja, que regresó a su tierra por encontrarse enfermo y, a raíz de ello, fue nombrado Académico Supernumerario a propuesta del Marqués de Santa Cruz en marzo de 1777; AASF, Juntas Ordinarias (1776-1785), sig. 84-3, fol. 49 v.; CeÁn Bermúdez, Juan Agustín: Op. cit., tomo IV, p. 305; AzAnZa LóPez, José Javier: "El papel regulador de la Real Academia de San Fernando en la implantación del Neoclasicismo en Navarra", Ondare: Cuadernos de Artes Plásticas y Monumentales, n. 21 (2001), p. 161, nota 14. Y otro escultor más, José Antonio Vinacer, tirolés establecido en Toledo, declaraba orgulloso ser discípulo suyo; Nicolau Castro, Juan: "El escultor Juan Pascual de Mena", Goya, n. 214 (1990), p. 204.

Durante la redacción final de este trabajo conocimos la publicación de una tesis doctoral sobre Pascual de Mena, donde se dedican algunas páginas a los discípulos del toledano. En ellas aparecen Arali, Arias, Rodríguez, Tolsá, Salesa y Vinacer, junto a otros como José Puchol Rubio, Pedro Estrada o Juan Pérez de Castro, con abundantes noticias que demuestran la relación con el maestro; vid. Pérez De Domingo, Lorenzo: El escultor Juan Pascual de Mena en Madrid, Madrid, FUE, 2007, pp. 42-45. 
Aunque no se puede asegurar el magisterio directo de Pascual de Mena -no hemos hallado documentos que lo prueben-, sí podemos afirmar que el arte de Del Cid guarda una estrecha relación con el del toledano. Y más aún; habría que apuntar también la posible influencia de Luis Salvador Carmona (1708-1767), profesor también de la Academia, en particular en lo que se refiere a la expresividad de los rostros, aspecto que trataremos más adelante ${ }^{11}$.

Por otra parte, pensamos que nuestro escultor habría nacido alrededor de la segunda década del siglo, quizá algo después, a juzgar por las edades conocidas de algunos de los aspirantes al premio. Y, casi con toda seguridad, no era oriundo de Madrid, dado que la documentación siempre se refiere a él como "vezino" de la villa, y no como natural de ella"

En 1763 lo encontramos establecido en Madrid como maestro escultor. Es entonces cuando realiza tres imágenes para el retablo mayor de la iglesia talaverana de San Salvador de los Caballeros: el Salvador, que preside el retablo como titular de la iglesia, San José con el Niño y San Vicente Ferrer. Por la ejecución y el transporte de la primera Del Cid cobró 2.760 reales; por las otras dos tallas cobró 2.600 reales $^{13}$.

La obra del retablo fue realizada por el ensamblador toledano Pedro de Luna entre 1761 y 1762 en sustitución de otro anterior de Andrés Martínez, también ensamblador, terminado en 1604. El conjunto sería dorado unos años después, entre 1768 y 1770, por el talaverano Luis de Salcedo ${ }^{14}$. En efecto, el retablo era nuevo, y presumiblemente hubo de encargarse ante el mal estado de conservación del precedente, pues en la visita eclesiástica de abril de 1743 ya se había señalado este punto:

"Altares, e Imágenes: El retablo del Altar maior, con su custodia, y tabernáculo y vn quadro grande en medio con la transfiguraz(i)ón del Señor, está Dorado y mui viejo"15.

11 Salvador Carmona obtuvo menos recompensas en la Academia que Pascual de Mena -también moriría mucho antes-, ocupando sólo los cargos de Académico de Mérito (1752-1765) y Teniente Director (1752-1765). Junto a él se formaron su hijo Bruno - dibujante- y sus sobrinos José - escultor-, Manuel y Juan Antonio Salvador Carmona -grabadores-, y los escultores Francisco Gutiérrez, Manuel de Acebo y Alfonso Chaves -a quien Ceán llama Francisco-; CEÁN BermúdeZ, Juan Agustín: Op. cit., tomo IV, p. 311; Martín GonZÁlez, Juan José: Luis Salvador Carmona. Escultor y Académico, Madrid, Alpuerto, 1990; Escultura barroca en España, 1600-1770, Madrid, Cátedra, 1998 (3. ${ }^{a}$ edición), pp. 380-390; García Gaínza, María Concepción: El escultor Luis Salvador Carmona, Burlada (Navarra), Universidad de Navarra, 1990, pp. 121-124.

12 Nicolau CAStro, Juan: Escultura toledana del siglo XVIII, Toledo, IPIET, 1991, p. 222; AzANZA LóPEZ, José Javier: Op. cit., p. 154.

${ }^{13}$ El 7 de octubre de 1763 se le pagan 2.580 reales por realizar la imagen del Salvador y 180 por su transporte. Todos estos datos fueron publicados por NiCOLAU CASTRO, Juan: Escultura toledana..., op. cit., p. 222. Este autor señala que "dado el precio que cobró por el conjunto, debió ser escultor apreciado, al menos, en el Madrid de mediado el siglo"; NiCOLAU CASTRO, Juan: Ibid.

En fecha reciente las tres imágenes han sido recogidas por Lorenzo Pérez atribuyéndolas a Pascual de Mena, quien no debía conocer la publicación de 1991 realizada por Nicolau; también son erróneas las medidas de las piezas; PÉREZ DE Domingo, Lorenzo: El escultor Juan Pascual..., op. cit., pp. 235-237.

${ }^{14}$ Nicolau Castro, Juan: Escultura toledana..., op. cit., pp. 66, 74-75 y 222, figs. 40-42. Véase nota infra, n. ${ }^{\circ} 15$.

15 Archivo de la Colegiata de Talavera de la Reina [ACTR], Parroquia de San Salvador de los Caballeros, libro 494, fol. 131; libro catalogado por Mendoza Eguaras, Mercedes y Torroja MenÉndez, Carmen: Catálogo analítico del Archivo de la Colegiata de Talavera de la Reina (1204-1900), Toledo, IPIET, 1969, p. 270, n. ${ }^{\circ}$ cat. 1.986, Inventario de alhajas, ornamentos y objetos de culto. La pintura que presidía el retablo era de la mano de Bernardino de la Agua; vid. Nicolau CASTRo, Juan: Escultura toledana..., op. cit., p. 74.

Posteriormente, en una visita realizada en 1770, ya se anotó la nueva obra: "En Visitta de 770 [1770], es el rettablo de talla nuebo, con su cascarón, Dorado todo, y en medio la efigie de el Salbador, y a los lados S(a)n Vizente ferrer y S(a)n Joseph con su niño; que su costte se abonó del rettablo en quentta del año de 762 [1762]; y del Dor(a)do en 770 [1770]."; ACTR, Parroquia de San Salvador de los Caballeros, libro 494, fol. 131. Años después, en 1789, se registró "una Nuestra Señora de la Conzepción" que se había añadido al retablo, y que hoy ya no se encuentra en él; ACTR, ibid. 
Todo el conjunto se encuentra en la actualidad en la iglesia parroquial de Parrillas (Toledo ${ }^{16}$. El retablo es de madera dorada, y se estructura en dos cuerpos sobre un banco y tres calles. Corresponde a la tipología conocida como "retablo-hornacina"17, y destaca el juego volumétrico de formas cóncavo-convexas de sus calles. Integra en la estructura arquitectónica una abigarrada decoración de talla y esgrafiado de diversos elementos (guirnaldas florales, rocallas, jarrones, rayos, óvalos, etc.), donde las diferentes imágenes rompen con la áurea monotonía del conjunto -las tres figuras ejecutadas por Del Cid, pero también la figura de Dios Padre, la paloma del Espíritu Santo, los angelillos y numerosas cabezas de querubines- ${ }^{18}$. Una obra que Nicolau ha calificado como "uno de los más bellamente rococó de la provincia de Toledo"19.

La imagen del Salvador que preside el retablo representa el momento de la Transfiguración del Señor, como explicitan los documentos (fig. 1). Su rostro es de una elegante belleza, alargadas proporciones y una expresión arrobada de barroco dramatismo. Cristo luce una túnica blanca con las bocamangas dobladas y un amplio manto de un tono blanco sutilmente azulino -en algunos intersticios se aprecian mejor las veladuras azuladas-; éste, sobre el hombro izquierdo y recogido en la cintura, envuelve su cuerpo en sentido diagonal. Los pliegues son amplios y de suaves volúmenes. Sólo una cenefa dorada de motivos vegetales decora los ribetes del manto y de la túnica. El gesto también es algo teatral, con las manos y los brazos abiertos -el derecho adelantado y alzado-, y el rostro y la mirada dirigidos hacia las alturas; los brazos dibujan una diagonal que se cruza visualmente con el manto oblicuo. Los amplios ropajes dejan entrever su postura anatómica: la pierna diestra algo abierta y flexionada, y la parte superior del cuerpo basculando hacia este lado. La figura se eleva sobre una gran peana de nubes; y encuentra su correspondencia en el eje vertical con la paloma del Espíritu Santo y el Padre Eterno, en una especie de teofanía trinitaria de ritmo ascendente ${ }^{20}$. Las dimensiones de la talla son algo mayores que el tamaño natural ${ }^{21}$.

Encontramos cierta semejanza entre la gestualidad triunfal de esta figura y la que tenía la desaparecida imagen de San Isidro que Pascual de Mena ejecutó para la colegiata madrileña de

${ }^{16}$ El párroco de este lugar nos comunicó que el retablo fue trasladado en 1995 procedente de la parroquia de San Salvador de los Caballeros de Talavera de la Reina (Toledo); vid. GómEz JARA, Jesús y GómEz GómEz, José María: Parroquia de Ntra. Sra. de la Luz, Parrillas (Toledo). Restauración e instalación del retablo mayor, Talavera de la Reina, Parroquia de Ntra. Sra. de la Luz, Parrillas, 1995. De este modo se desvirtuó la visión del conjunto, pues el espacio para el que fue diseñado originalmente -la cabecera poligonal mudéjar de la iglesia de San Salvador- era más estrecho que el amplio testero recto de la parroquial de Parrillas. Igualmente, el altar original se modificó tras la reforma litúrgica emanada del Concilio Vaticano II (1962-1965) -habría que decir, más bien, a raíz de una errónea interpretación de las normas conciliares-, como ocurrió en muchos templos españoles.

Unos años después se colocarían en él las esculturas originales de San José con el Niño y San Vicente Ferrer, que anteriormente habían permanecido en una capilla de la Colegial de Talavera de la Reina; vid. PACHECo JiMÉNEZ, César: "El culto de San José en Talavera de la Reina. Arte y devoción en el Antiguo Régimen", Alcalibe, n. ${ }^{\circ} 4$ (2004), pp. 181182. Agradecemos a su autor la noticia.

17 Recogemos la terminología difundida por MARTín GonZÁLez, Juan José: El retablo barroco en España, Madrid, Alpuerto, 1993, p. 15.

${ }^{18}$ Los pagos documentados a Del Cid se refieren a las tres tallas citadas anteriormente. El resto de figuras pueden deberse a otro escultor, quizá del mismo taller, pues parecen de una calidad inferior, aunque no estamos seguros.

19 Nicolau Castro, Juan: Escultura toledana..., op. cit., p. 75. Éste ofrece una descripción exhaustiva del conjunto.

${ }^{20}$ La iconografía de esta imagen de Cristo, con vestiduras blancas "como la luz", la aparición nebulosa y la presencia de Dios Padre, se corresponde, en cierto modo, con el relato evangélico que la inspira (Mateo 17, 1-13; Marcos 9, 2-13; Lucas 9, 28-36).

${ }^{21}$ Lamentamos no poder ofrecer las dimensiones exactas de las figuras. Aproximadamente, la talla del Salvador ha de tener unos $200 \mathrm{~cm}$. de altura, mientras que las otras dos han de medir unos $165 \mathrm{~cm}$. - es decir, unas 2 varas castellanas-. 


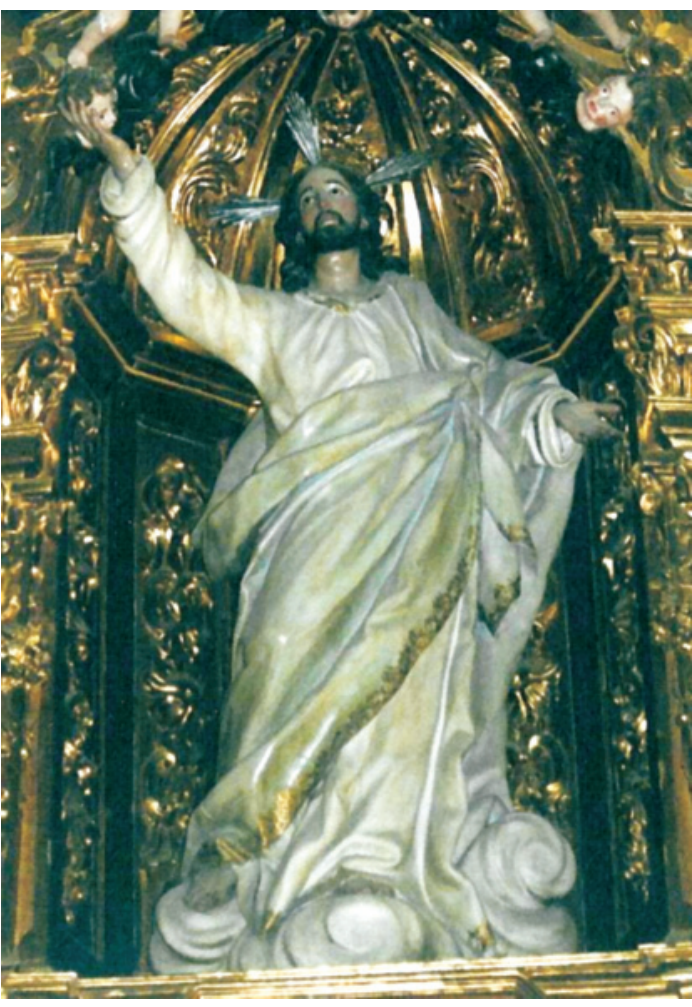

Fig. 1. Fernando del Cid. Transfiguración de El Salvador. 1763. Iglesia parroquial de Parrillas (Toledo).
San Isidro el Real en $1768^{22}$; ambos varones extienden los brazos describiendo una diagonal y elevan la mirada hacia lo alto, entroncando de este modo con el espíritu barroco, si bien algo atemperado por el gusto de la época.

En la hornacina de la izquierda -desde nuestro punto de vista- se encuentra la talla de San José con el Niño (fig. 2). La cabeza del santo guarda gran parecido con el modelo del Salvador. Su cuerpo adopta cierto movimiento, apoyado en el bastón con la mano derecha, la pierna izquierda flexionada, arrastrando el pie, y el rostro girado su lado izquierdo, donde sostiene al Niño Jesús sobre un lienzo blanco. El pequeño, de cabellos rubios, mantiene una postura inestable y juguetona. Sin embargo, ambas figuras no cruzan sus miradas: el santo se gira para contemplar al Niño, mientras que Éste dirige su mirada hacia nosotros. En nuestra opinión, la figura graciosa e inquieta del Niño, junto con la firme mano que lo sostiene sobre el blanco fondo del lienzo, es lo más notable de la pieza. La túnica es de un azul grisáceo y el manto, de tono asalmonado, envuelve parcialmente a la figura; una cenefa dorada semejante a la anterior decora los ribetes. La peana es de planta rectangular, y su sección muestra una escocia central, jaspeada en un tono anaranjado y limitada por sendos listeles dorados.

Nos parece evidente la relación de esta talla con otras semejantes atribuidas a Juan Pascual de Mena. El modelo más cercano es el que se encuentra en la capilla de la Presentación de la catedral de Burgos, cuya composición y trabajo de talla es muy similar. Sólo hemos podido examinar la pieza a través de fotografías, pero, si efectivamente es obra del escultor de la Sagra toledana, demuestra una íntima conexión con el arte de Del Cid ${ }^{23}$. Otro San José con el Niño atribuido al toledano que ofrece algunas semejanzas se encuentra en el convento de

22 Cfr. Pérez De Domingo, Lorenzo: El escultor Juan Pascual..., op. cit., pp. 174-176, fig. 67.

${ }^{23}$ El trabajo de Burgos es muy posterior, pues el pago de la obra se realizó en 1782; vid. Catálogo de la exposición (Valladolid, 1988): Las Edades del Hombre. El arte en la Iglesia de Castilla y León, Salamanca, Caja de Ahorros de Salamanca-Junta de Castilla y León, 1988, p. 299 (ficha a cargo de Alberto C. Ibáñez Pérez); Pérez De Domingo, Lorenzo: El escultor Juan Pascual..., op. cit., p. 190. El precio de la imagen fue de 880 reales -630 por la talla y 250 por su "estofado y compostura"-, cuyo bajo coste sorprende, con razón, a Pérez de Domingo: lo compara con los 5.000 reales que cobró Pascual de Mena en 1770 por el San Juan de Sahagún de la misma catedral. Quizá esta diferencia en los precios se deba a que el San José fuera realizado por otro artista de menor prestigio que el célebre académico. ¿Sería nuestro escultor? También pueda ser significativo el que Ponz cite el San Juan de Sahagún explicando que su autor era "D. Pasqual de Mena" -su antiguo compañero académico- y ni siquiera mencione la segunda escultura; PonZ, Antonio: Viage de España, tomo XII, Madrid, Viuda de Ibarra, Hijos y Compañía, 1788 (3. edición, corregida y aumentada), Carta Segunda, p. 33, n. ${ }^{\circ} 28$ (1. ${ }^{\mathrm{a}}$ edición del tomo XII: Madrid, Joaquín Ibarra, 1783). 
Madres Carmelitas de Talavera de la Reina ${ }^{24}$, que Nicolau relaciona, a su vez, con otro conservado en el Monasterio de la Encarnación (Madrid). Todos los ejemplos citados se alejan del prototipo creado por Salvador Carmona, de un mayor barroquismo en todos los sentidos ${ }^{25}$.

En la hornacina contraria está la imagen de San $\mathrm{Vi}$ cente Ferrer (fig. 3) ${ }^{26}$. El santo, en actitud predicadera -casi podríamos decir declamatoria-, como es habitual en su representación, repite la posición del brazo que ofrece el Salvador ${ }^{27}$. Obviamente, la iconografía tradicional del santo sirvió de guía al escultor que, sin embargo, no incluyó el libro -otras veces es una filacteria- que suele acompañar al dominico como atributo; en su lugar, éste recoge de modo elegante la capa con la mano izquierda ${ }^{28}$. Por otra parte, la calidad intrínseca del hábito dominico hubo de condicionar el menor lucimiento en el trabajo de los plegados, más sencillos que los anteriores. El trabajo sumario de las ropas, junto a la expresión un tanto ensimismada del rostro, hacen que esta figura sea la que transmite menor viveza de las tres; no obstante, nos parece una imagen de bastante calidad ${ }^{29}$. El atuendo,

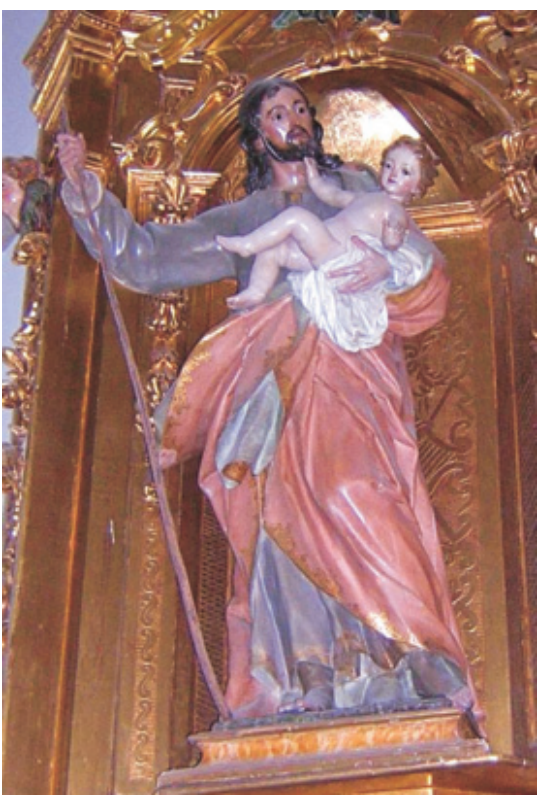

Fig. 2. Fernando del Cid. San José y el Niño. 1763. Iglesia parroquial de Parrillas (Toledo).

${ }^{24}$ Nicolau Castro, Juan: "Dos posibles obras desconocidas de Juan Pascual de Mena", Archivo Español de Arte, n.os 177-180 (1972), pp. 63-66. Ambas tallas fueron comparadas por este mismo autor en NicolaU CASTRO, Juan: Escultura toledana..., op. cit., p. 222, figs. 194 y 220.

25 Vid. García GaínZa, María Concepción: Luis Salvador Carmona en San Fermín de los Navarros, Madrid, Real Congregación de San Fermín de los Navarros, 1990, pp. 45-51. Además de las publicadas por García Gaínza, otras tallas de San José con el Niño de este escultor o a él atribuidas pueden verse en MARTín GonZÁLEZ, Juan José: Luis Salvador Carmona..., op. cit., pp. 164, 167, 234-235 y 245-247.

${ }^{26}$ Imagen que pudo contemplarse en una exposición celebrada en el año 2005 en Toledo; véase el catálogo: $A$ imagen y semejanza. 1.700 años de Santidad en la Archidiócesis de Toledo, Madrid, Instituto Teológico San Ildefonso, 2004, p. 249 (ficha a cargo de Juan Nicolau Castro).

$27 \mathrm{Al}$ margen de indicar la actitud oratoria de San Vicente, el gesto nos dirige visualmente hacia la figura de Cristo transfigurado. No es nuestro propósito estudiar el sentido iconológico del conjunto; sin embargo, no queremos dejar de apuntar algunas cuestiones. La advocación de la iglesia de San Salvador viene de antiguo -es citada a mediados del siglo XII- (ABAD CAStro, María Concepción: Arquitectura mudéjar religiosa en el Arzobispado de Toledo, tomo II, Toledo, Caja de Ahorro de Toledo, 1991, pp. 212-213), y, como se ha dicho, el cuadro que presidía el retablo precedente, de comienzos del siglo XVII, ya representaba al Salvador como Cristo transfigurado. No conocemos el motivo de haber incluido juntos en este retablo a San José y a San Vicente Ferrer; la única conexión que se nos ocurre es la gran devoción que hacia ambos se tenía en tierras valencianas. Por otra parte, el culto a San José fue especialmente fomentado por la Orden del Carmen, y el convento de las Madres Carmelitas Descalzas se encuentra muy próximo a la parroquia, justo en frente, aunque no sabemos si esta circunstancia pudiera ser relevante en este caso. Sobre esta devoción en la ciudad remitimos a PACHECO JimÉNEZ, César: "El culto de San José en Talavera...", op. cit., pp. 163-192. Un examen atento de la antigua documentación de San Salvador de los Caballeros tal vez resolvería estos interrogantes, que consideramos de suma importancia para la comprensión del conjunto.

${ }_{28}$ De este modo, por ejemplo, aparece también en un lienzo de la Predicación de San Vicente Ferrer de Francisco Ribalta que se encuentra en la iglesia parroquial de Algemesí (Valencia). Otra variante pictórica en la que el santo se agarra la capa es la que se atribuye a Alonso Cano (Colección Santander Central Hispano, Madrid; Colección Caja de Ahorros de Valencia).

${ }^{29}$ Creemos excesiva la crítica desfavorable emitida en Nicolau CASTRO, Juan: La escultura toledana..., op. cit., p. 222. 


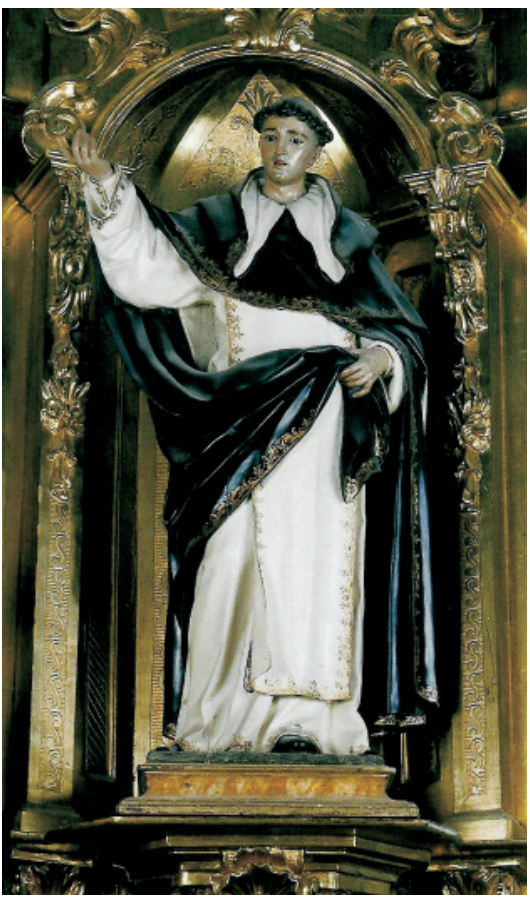

Fig. 3. Fernando del Cid. San Vicente Ferrer. 1763. Iglesia parroquial de Parrillas (Toledo).

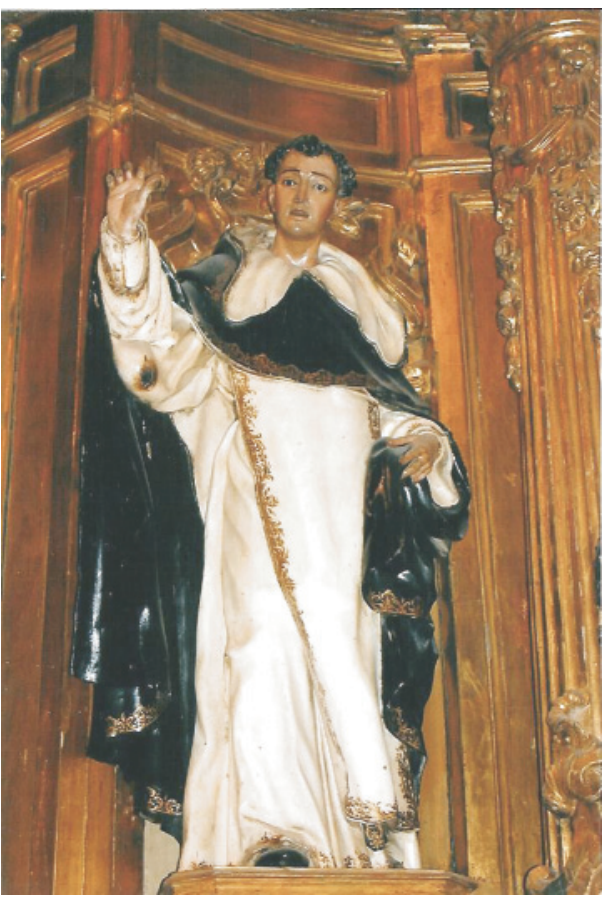

Fig. 4. San Vicente Ferrer. H. 1771. Iglesia parroquial de Falces (Navarra).

blanco y negro, está ribeteado con la correspondiente cenefa dorada. La peana es semejante a la del San José.

Al ver esta talla nos viene a la memoria el santo homónimo conservado en la capilla de la Virgen del Rosario de la iglesia de la localidad navarra de Falces, atribuido hace años al círculo de Luis Salvador Carmona y, más recientemente, a Juan Pascual de Mena, y fechado en torno a 1771 (fig. 4$)^{30}$.

Como ya hemos señalado, el recuerdo de los modelos de Pascual de Mena en las tres piezas de San Salvador es evidente; y también se acerca Del Cid a su modo de tallar los ropajes. Pero también podemos apreciar cierto influjo de la obra de Salvador Carmona; por supuesto, Del Cid

30 AA.VV.: Catálogo monumental de Navarra. vol. III. Merindad de Olite, Pamplona, Comunidad Foral de Navarra-Institución Príncipe de Viana, 1985, p. 87, láms. 132 y 133; PéReZ De Domingo, Lorenzo: El escultor Juan Pascual..., op. cit., p. 226, fig. 140. Ambas imágenes guardan una estrecha relación, aunque la de San Salvador resulta más lograda, más elegante. Por otra parte, el Santo Domingo de Guzmán que hace pareja con la talla de Falces, así como la Virgen del Rosario que preside el retablo, ofrecen rasgos comunes a otras obras de nuestro escultor, o a él atribuidas, como después veremos. Baste señalar, por ahora, la similitud en la manera de disponer y tallar el manto de la Virgen del Rosario con los atuendos correspondientes al Salvador y al San José de la iglesia talaverana. En definitiva, cabe preguntarse si podrían deberse a nuestro escultor o a su taller las tres tallas de la parroquia navarra de Falces. Además, García Gaínza recoge que las tres tallas fueron traídas de Madrid, al igual que otras tantas -de la Inmaculada, San Joaquín y Santa Ana- que se encuentran en el retablo de la Inmaculada Concepción, en la capilla de enfrente, y que la autora atribuye a José Salvador Carmona; AA.VV.: Catálogo monumental de Navarra..., op. cit., pp. 84-85 y 87; GARCÍA GAÍNZA, María Concepción: El escultor Luis Salvador..., op. cit., p. 103. 
no llega al virtuosismo técnico y expresivo del vallisoletano, pero sí se advierte en él un deseo por dotar a sus obras de una mayor expresividad, particularmente en los rostros, que lo acerca al maestro de Nava del Rey.

En relación con las piezas que Del Cid realizara para San Salvador queremos hablar de otras dos tallas hasta ahora atribuidas a Juan Pascual de Mena o a su círculo más próximo ${ }^{31}$. Se trata de un San Andrés Corsino y una Santa María Magdalena de Pazzi que actualmente se encuentran en la iglesia parroquial de Hinojosa de San Vicente (Toledo). Ambas imágenes proceden del retablo mayor del convento del Santo Desierto del Piélago, perteneciente a la Orden de Carmelitas Calzados, y cuyas ruinas aún permanecen dentro del término municipal de Hinojosa ${ }^{32}$. Sabemos que la nueva iglesia del convento se inauguró en septiembre de 1741, sustituyendo el destino de la antigua ermita de Nuestra Señora del Piélago. Sin embargo, es probable que el exorno de su interior se prolongara durante años, quizá décadas; la fábrica del nuevo templo habría resultado muy costosa para una comunidad fundada hacía relativamente poco tiempo, en 1687, y, en consecuencia, se tardaría un tiempo en acometer una empresa como la del retablo mayor. Por ello, y a falta de la documentación precisa, pensamos que el retablo se hubo de realizar en algún momento entre 1745 y 1760, o incluso algo después.

Conocemos cómo era gracias al testimonio de Matías Gómez de Morales, escribano de Hinojosa y circunstancial historiador local, que unos años después de su realización, concretamente en 1773, lo describía de este modo:

"El retablo del altar mayor es de muy curiosa escultura y dorado a toda costa; tiene en su medio el tabernáculo, guarnecido de cristales el cascarón; por cima está colocada, como patrona de este Real Convento, Nuestra Señora de los Ángeles, ocupando el principal nicho; recátala un bellísimo velo, y sólo se corre cuando se dice la misa conventual o se hace alguna velada por persona de distinción, y entonces aparece todo el trono bien prevenido de luces sobre candeleros y arañas (...) A los lados tiene dos imágenes muy primorosas de talla, la una de San Andrés Corsino y la otra de Santa María Magdalena de Pacis, con diferentes Ángeles que dan su música a esta Soberana Reina; en su remate está el Espíritu Santo, recreándose en ver a esta Señora"33.

Probablemente, la composición general del retablo no diferiría mucho del que se hizo para la iglesia talaverana de San Salvador: una obra de dos cuerpos y tres calles, la imagen titular en el nicho central, por encima del tabernáculo, un rompimiento de Gloria más arriba y dos santos formando pareja a ambos lados del retablo.

Durante el proceso desamortizador impulsado por Mendizábal (1835-1837) el convento hubo de ser definitivamente abandonado. Como consecuencia de esto, algunos de los bienes se repar-

31 Atribución realizada por NiCOLAU CASTRO, Juan: “Aportaciones a la escultura de Luis Salvador Carmona y Juan Pascual de Mena”, Boletín del Seminario de Estudios de Arte y Arqueología, LIV (1988), pp. 477 y 478; La escultura toledana..., op. cit., p. 238, nota 9; "Algunas noticias sobre el arte religioso en la Sierra de San Vicente", Boletín de la Sociedad de Amigos de la Sierra de San Vicente, n. ${ }^{\circ} 3$ (1992), p. 102.

32 Para un mayor conocimiento sobre la historia y el patrimonio artístico del Real Convento del Piélago remitimos al trabajo de SÁnchez Manzano, Esteban y SÁnchez Rivera, Jesús Ángel: La Sierra de San Vicente y la Villa de Hinojosa, Madrid, Eurídice, 2004, pp. 72-78, 93-95 y 182-204. En la actualidad preparamos un estudio con nuevas noticias y precisiones sobre esta fundación que vendrá a ampliar aquel trabajo.

33 Gómez de Morales, Matías: La Historia de la descripción del Santuario de la Sierra de San Vicente del Piélago, cueva de los Santos hermanos mártires San Vicente, Santa Sabina y Santa Cristeta, milagros, señas y aparición de Nuestra Señora de los Ángeles, propia de esta villa de la Hinojosa..., 1773, cap. 7. ${ }^{\circ}$, VIII; manuscrito copia del original, escrito en 1919, que se halla en el Archivo Parroquial de Hinojosa de San Vicente [APIC], caja 18, libro 16. 
tieron entre las parroquias circundantes, entre ellos las imágenes de los santos carmelitas que ocupaban el referido retablo.

Al estudiar detenidamente las piezas del Piélago hace unos años mantuvimos ciertas reservas sobre la atribución a Pascual de Mena, señalando los elementos que entroncaban con la producción del toledano, pero también apuntando las diferencias, más que notables, que existen con su $\operatorname{arte}^{34}$. De lo que no nos cabía duda era de la filiación madrileña de las obras, que se puede rastrear en una serie de elementos formales comunes al ámbito de la Villa y Corte durante este periodo ${ }^{35}$.

San Andrés Corsino (160 cm. de alto) representa al santo carmelita de noble linaje florentino nacido en 1302 (figs. 5 y 6). Vestido con el hábito de la Orden, de la que era patrón, sujeta un báculo dorado con la mano diestra y tiene a sus pies la mitra episcopal. Dichos atributos revelan la dignidad que ostentó desde 1360 hasta 1373: Obispo de Fiésole. Además, en su mano izquierda sostiene un libro abierto que indica su condición de teólogo - carrera que estudió en París-. El origen de su iconografía se remonta al siglo XVII, pues fue canonizado en 1629. Pero fue Clemente XII, papa entre 1730 y 1740, quien promovió su culto especialmente, dado que era descendiente de la familia del santo, los Corsini ${ }^{36}$. A la luz de este dato ya sugerimos la hipótesis de que, en coincidencia con el papado de Lorenzo Corsini, o quizá inmediatamente después, se encargara la imagen del Santo carmelita para el nuevo templo, que se concluyó diecinueve meses después de la muerte del pontífice ${ }^{37}$. Hoy seguimos manteniendo esta sugestiva hipótesis, aunque pensamos que habría que retrasar la fecha de ejecución -y quizá también la de encargo- del retablo.

Muy lograda en sus proporciones, esta figura transmite una elegante serenidad. En un ligero contrapposto, con la cabeza girada hacia el libro y la pierna derecha hacia el lado contrario, la talla presenta una disposición vertical que aporta el equilibrio compositivo necesario. El trabajo de las ropas es notable, aunque no excesivamente complejo: cae el hábito de forma natural, con pliegues gruesos, y recogido sobre el brazo izquierdo. Lo mismo se puede decir del rostro, casi táctil; el santo está concentrado en su lectura, con una boca entreabierta que le da mayor viveza. También las manos otorgan elegancia y naturalidad a la figura. La carnación del rostro y las manos es muy buena; la policromía de las ropas es más monótona, decoradas tan sólo con una pequeña cenefa de color dorado pintada a pincel. La peana que soporta la imagen es de forma ochavada y presenta un perfil moldurado (base, cuarto bocel, media caña y listel). Ésta y el báculo están dorados. Hace pocos años fue restaurada junto con su compañera, pues se encontraban en un estado de conservación lamentable.

\footnotetext{
34 SÁnchez Rivera, Jesús Ángel, "Los bienes muebles del convento del Piélago. Historia de un patrimonio disperso o desaparecido", Cuaderna. Revista de estudios humanísticos de Talavera y su antigua tierra, n. ${ }^{\circ} 11$ (2003), pp. 100102; "El convento de carmelitas calzados del Piélago (Toledo). Aportaciones para su estudio histórico-artístico", Carmelus, vol. 51 (2004), pp. 117-118; SÁnchez MANZANo, Esteban y SÁnchez Rivera, Jesús Ángel: Op. cit., pp. 195-199.

35 Así también lo señalamos en SÁnchez Rivera, Jesús Ángel: "Dos tallas madrileñas del siglo XVIII procedentes del convento carmelita del Piélago en la parroquia de Hinojosa de San Vicente", Aguasal, n. ${ }^{\circ} 31$ (2004), pp. 20-21. Recientemente las piezas han sido citadas en dos publicaciones por PÉrez De Domingo, Lorenzo: "La obra del escultor Juan Pascual...", op. cit., pp. 308-309; El escultor Juan Pascual..., op. cit., pp. 234-235. Éste último trabajo las recoge sin haberlas visto in situ, y no añade nada nuevo a lo dicho por Nicolau en 1988.

${ }^{36}$ Para la biografía e iconografía de San Andrés Corsino hemos manejado: SAGgi, Ludovico (O. Carm.): Santos del Carmelo. Biografias de diversos diccionarios, Madrid, Editorial de Espiritualidad, 1982, pp. 230-240 (Primera edición: Roma, Institutum Carmelitanum, 1972).

${ }^{37}$ Hay que recordar también que, por expreso deseo de Clemente XII, éste fue enterrado en una capilla dedicada a su santo antepasado, construida en la basílica romana de San Juan de Letrán entre 1732 y 1735.
} 


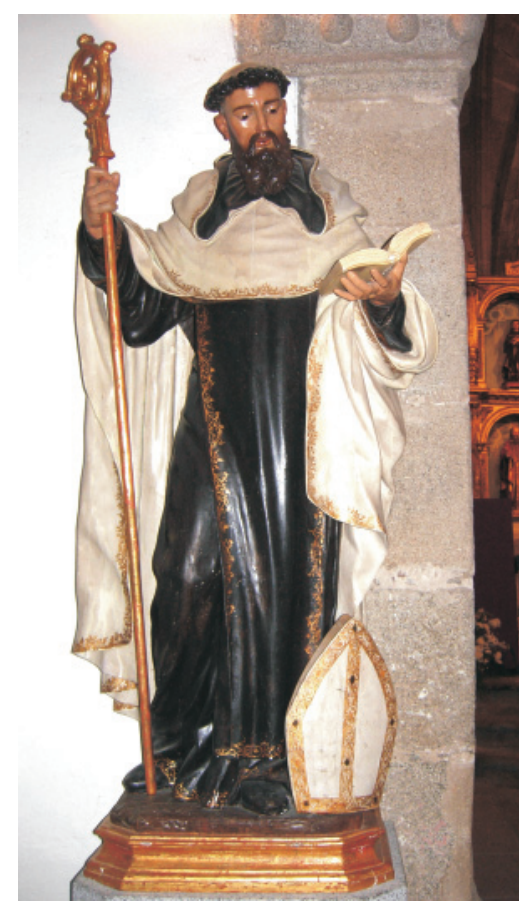

Fig. 5. San Andrés Corsino.

H. 1745-1765. Iglesia parroquial de Hinojosa de San Vicente (Toledo).

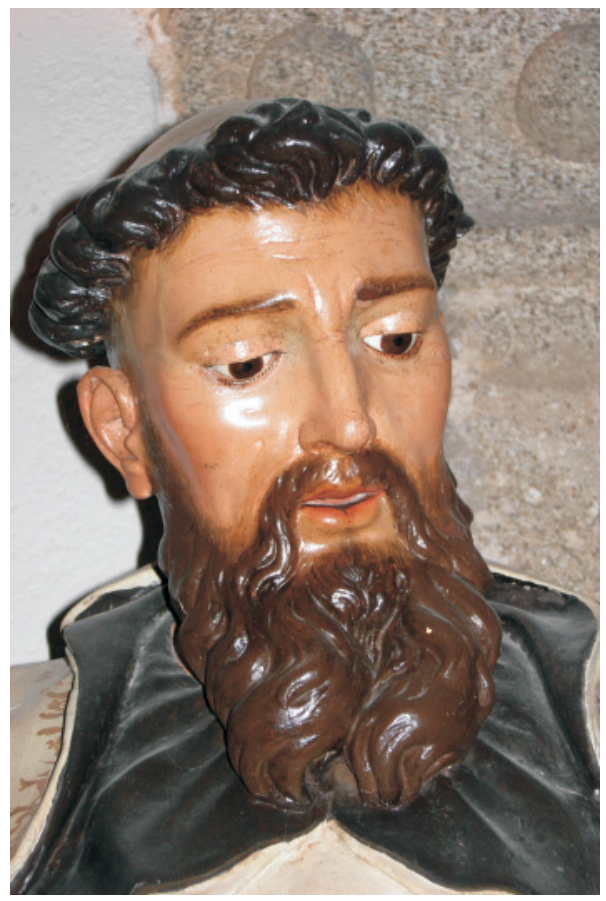

Fig. 6. San Andrés Corsino, detalle. H. 1745-1765. Iglesia parroquial de Hinojosa de San Vicente (Toledo).

Santa María Magdalena de Pazzi -o de Pacis, castellanizado- también había nacido en Florencia, en 1566. Y también había pertenecido a la Orden del Carmen. Murió en 1607, siendo canonizada sesenta y dos años después; entonces fue adoptada como patrona de los carmelitas. En nuestra opinión, la presencia de esta santa en el retablo encuentra su razón de ser en la nueva advocación que los frailes carmelitas quisieron asignar a la antigua imagen de la Virgen del Piélago, también llamada Virgen del Espino; los nuevos moradores del lugar sustituyeron las denominaciones bajomedievales de esta Virgen por otra con la impronta de su Orden, concretamente Virgen de los Ángeles, en recuerdo de aquel convento de Santa Maria degli Angeli (Florencia) donde vivió la santa ${ }^{38}$. Además, como ya hemos dicho, se trata de una santa florentina, al igual que San Andrés Corsino, y la elección de ambos para el altar mayor ha de tener una íntima conexión ${ }^{39}$. En esta talla (de $163 \mathrm{~cm}$. de altura) aparece representada con hábito carmelitano y con

38 Así lo apuntamos en SÁnchez Rivera, Jesús Ángel: "Los bienes muebles del convento del Piélago...”, op. cit., p. 99 , nota 8 .

39 Sabemos que en 1757 era fraile del convento "Matheo de S(ant)a Pazis", que debía de ser uno de los nuevos ordenados en el Piélago pues firma de los últimos, conforme a la jerarquía observada en la comunidad. La elección de su nombre indica el fomento de la devoción a Santa María Magdalena de Pazzi en aquel lugar; Archivo Histórico Provincial de Toledo (AHPT), Jacinto Muñoz, Prot. n. ${ }^{\circ}$ 14.083, fols. 88 r.-89 v. (Agradecemos esta noticia a David Gutiérrez Pulido). Para hacerse una idea de la devoción y del culto a estos santos florentinos en España, en especial a la Santa, vid. Velasco BAYón, Balbino (O. Carm.): Historia del Carmelo español, vols. II y III, Roma, Institutum Carmelitanum, 1992 y 1994; Los carmelitas. Historia de la Orden del Carmen, IV. El Carmelo español (1260-1980), Madrid, BAC, 1993. 


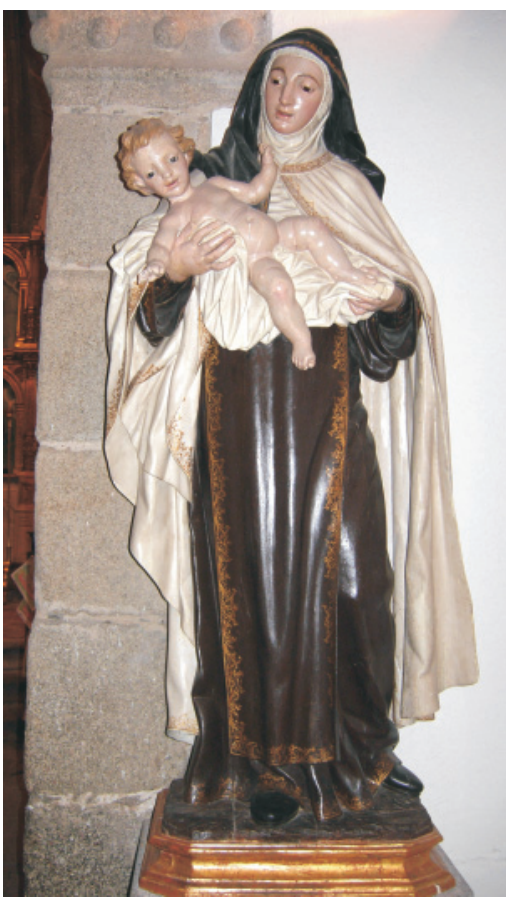

Fig. 7. Santa María Magdalena de Pazzi. H. 1745-1765. Iglesia parroquial de Hinojosa de San Vicente (Toledo). el Niño Jesús en los brazos, siguiendo la tradición hagiográfica según la cual la santa habría tenido una experiencia mística en la que la Virgen le entregó a su Hijo (fig. 7) ${ }^{40}$.

Esta figura es parecida a la anterior en lo concerniente a la postura y al trabajo de talla; la santa, colocada en el lateral derecho del retablo, dirigía su cuerpo hacia el centro del mismo, tal como hacía el santo desde el lado contrario. El elemento de mayor diferencia entre ambos es el Niño, que introduce cierto movimiento, grácil e inquieto; a la vez, añade un componente sentimental de ternura del que carecía la imagen del santo varón.

Ahora creemos poder atribuir estas dos obras a Fernando del Cid o, siendo más cautos, a su mismo taller. Comparando las imágenes procedentes del Piélago con las conservadas en la parroquia de Parrillas pensamos en una misma autoría para todas las piezas. El modo expresivo de representar los rostros, con la boca entreabierta, y el ceño ligeramente fruncido en virtud de una acción -San Andrés Corsino, leyendo, y San Vicente Ferrer, predicando-, permite establecer una misma filiación, a la vez que los aleja de las maneras de Juan Pascual de Mena, a quien se venían atribuyendo las tallas de Hinojosa. También el tratamiento de las vestiduras es muy semejante, con pliegues más gruesos, más simplificados, y de formas suaves y naturales ${ }^{41}$. Los rostros característicos -con las cejas en arco y la boca mostrando los dientes superiores-, el trabajo de los cabellos y de las manos, los modelos, incluso la composición de las figuras sugieren la intervención de un mismo artífice; por ejemplo, el modo de disponer al Niño Jesús en los brazos de San José y en los de la santa italiana, de cara al espectador y sobre un lienzo blanco, es parecido ${ }^{42}$. Las tallas de los cuatro santos, que se disponían por parejas a ambos lados de sus retablos correspondientes, son de tamaño natural -unas dos varas castellanas de altura-. Por último, el trabajo de la policromía de las piezas es prácticamente igual, hasta en los pequeños detalles decorativos, como las cenefas de motivos vegetales dorados realizadas a pincel que adornan los hábitos de los cuatro santos. En todos, las carnaciones resultan brillantes, pulimentadas.

A la hora de buscar modelos con los que comparar estas figuras hemos de referirnos a la producción del ámbito madrileño de la segunda mitad del siglo XVIII ${ }^{43}$. Algunas obras de Pascual de Mena resultan muy elocuentes para señalar las semejanzas y las diferencias entre ambos artistas. La figuras de San Benito Abad y Santa Escolástica Abadesa (iglesia de San Marcos, Madrid), realizadas en $1757 \mathrm{y}$, por tanto, muy cercanas a la fecha en que se hicieron las tallas del Piélago, ofrecen lejanas conexiones formales con las obras del Piélago. Sin embargo, un

40 SagGi, Ludovico (O. Carm.): Op. cit., pp. 393-418.

${ }^{41}$ Diferencias que ya manifestamos en SÁnchez RiverA, Jesús Ángel: "Los bienes muebles del convento del Piélago...", op. cit., p. 102.

${ }^{42}$ Sin embargo, la cabeza del Niño de Hinojosa resulta de una calidad inferior, lo que siembra ciertas dudas sobre la atribución a Del Cid. No obstante, hemos de saber que esta figura estaba muy estropeada antes de su restauración y, tras la intervención, su aspecto pudo quedar un tanto desvirtuado.

43 Vid. SÁnchez Rivera, Jesús Ángel: "Dos tallas madrileñas del siglo XVIII...”, op. cit., p. 21. 
examen comparativo más atento permite ver que las piezas de Pascual de Mena ofrecen un tratamiento más rico y movido del frente de sus hábitos, así como de la barba del santo; las tallas de Hinojosa, por el contrario, poseen rostros más expresivos: San Andrés embebido en su lectura, la santa con una mirada tierna hacia el Niño.

Una talla muy cercana al San Andrés Corsino es el Santo Domingo de Guzmán de Falces (Navarra) -a juzgar por las fotografías-, cuya pareja ya hemos citado en relación con el San Vicente Ferrer de San Salvador; dichas esculturas están también atribuidas a Pascual de Mena ${ }^{44}$. De coincidencias más imprecisas es el prototipo de San José utilizado por el toledano ${ }^{45}$. Por otra parte, el San Antonio Abad de la portada de las Escuelas Pías -antiguo monasterio de antoninos-, del que desconocemos la autoría, ofrece un modelo compositivo parecido al santo de Hinojosa. También habría que recordar ciertos modelos de Salvador Carmona; figuras como la de Santo Domingo de Guzmán (iglesia de San Esteban, Salamanca; iglesia de Santo Domingo, Cáceres) pueden recordar vagamente al santo carmelita ${ }^{46}$. Parece como si en estos trabajos el escultor del Piélago hubiese llegado a una solución híbrida entre la escultura de Pascual de Mena y la de Salvador Carmona, aunque no hay que descartar la relación con otros modelos que por entonces circulaban en el panorama artístico madrileño.

Santa María Magdalena de Pazzi, por su parte, ha sido comparada con otras piezas madrileñas, como la Santa María de Cervelló y la Beata Mariana de Jesús que Pascual de Mena realizara para el retablo mayor de la iglesia del Real Convento de Mercedarias de la Inmaculada Concepción -conocido vulgarmente como de las Góngoras_- ${ }^{47}$, o con la Santa Teresa de Jesús que permanece en el convento Madres Carmelitas de Talavera de la Reina, atribuida al mismo escultor ${ }^{48}$. Pensamos que la relación entre todas estas piezas responde más a una coincidencia en los modelos estéticos manejados por los escultores de la época que a una dependencia formal consciente o deliberada. Asimismo, el Niño Jesús que sostiene la monja guarda cierto parecido con otras figuras que el artista toledano hizo para sus imágenes de San José, como ya se ha señalado. Por último, y no menos importante, queremos indicar que la cenefa decorativa que ribetea el hábito de la monja florentina es prácticamente idéntico al que luce el San Vicente Ferrer de la navarra localidad de Falces; un elemento más para conectar ambos conjuntos con un mismo taller donde se policromaran las tallas.

Muy cerca del Piélago se encuentra la villa de Pedro Bernardo (Ávila), donde conocemos una talla inédita de San Juan Bautista bastante interesante (fig. 8) ${ }^{49}$. Su relación con el modelo creado por Pascual de Mena para la iglesia madrileña de San Fermín de los Navarros (desaparecida, fig. 9), o con el que se le atribuye en San Ginés (Madrid), resulta evidente ${ }^{50}$. Sin embargo, mien-

44 PÉrez de Domingo, Lorenzo: El escultor Juan Pascual..., op. cit., pp. 225-226. Tal vez un análisis exhaustivo de las mismas hiciera replantear la atribución a Pascual de Mena.

45 Vid. PÉrez DE Domingo, Lorenzo: Ibid., pp. 176 y 203 y figs. 68 y 104. El autor recoge, además, varias atribuciones con este asunto.

${ }^{46}$ Martín GonzÁlez, Juan José: Luis Salvador Carmona..., op. cit., pp. 259-260 y 266-267. Una tercera pieza, conservada en Madrid, pudo verse en el Catálogo de la Exposición Conmemorativa del Primer Centenario de la Diócesis Madrid-Alcalá, Madrid, Caja de Ahorros y Monte de Piedad, 1986, pp. 194-195.

47 SÁnchez Rivera, Jesús Ángel: "El retablo mayor de la iglesia del convento de mercedarias de la Purísima Concepción en Madrid”, Cuadernos de Arte e Iconografía, XIII, n. 25 (2004), p. 204, nota 26. PÉREZ DE Domingo, Lorenzo: "La obra del escultor Juan Pascual...", op. cit., pp. 308-309.

48 Nicolau CAStro, Juan: "Dos posibles obras desconocidas...", op. cit., pp. 63-66.

49 Expresamos nuestro agradecimiento a Juan Nicolau Castro, quien, con suma generosidad, nos dio a conocer la pieza, facilitándonos sus fotografías.

${ }^{50}$ La postura del santo y el cordero son semejantes, salvo el brazo derecho, que señala de modo elocuente al "Agnus Dei”, mientras que en los modelos de Madrid San Juan señala hacia lo alto. Muy parecida es la piel de camello y la disposición del manto, que, sin embargo, en este caso imita un tejido de color encarnado y ribeteado con una cenefa 


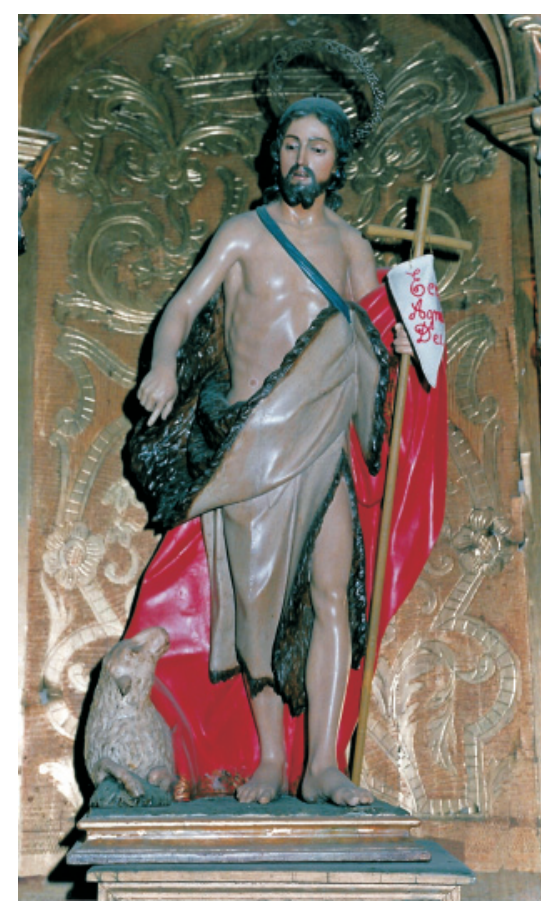

Fig. 8. San Juan Bautista.

H. 1747-1770. Iglesia parroquial de Pedro Bernardo (Ávila).

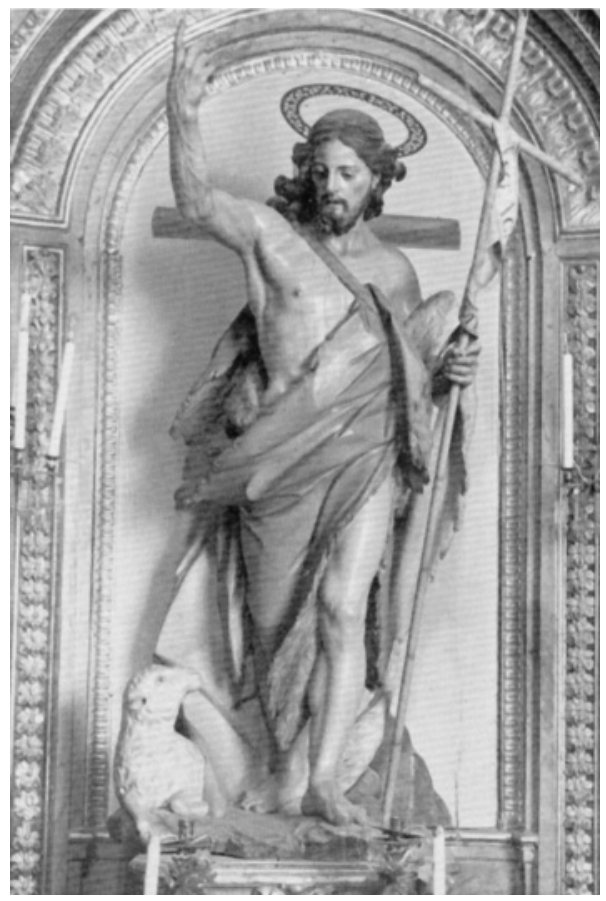

Fig. 9. Juan Pascual de Mena. San Juan Bautista. H. 1746. Iglesia de San Fermín de los Navarros, Madrid (desaparecida). Foto Moreno (tomada de P. Saguiés Azcona, 1963).

tras que la destruida pieza madrileña ofrecía una anatomía vigorosa y bellamente proporcionada, la del ejemplar abulense es más débil y estilizada; asimismo, el trabajo de los pliegues de su atuendo parece una simplificación de los que lucía aquélla. Con todas las cautelas posibles, atribuimos la obra a nuestro Fernando del Cid. Todo en ella recuerda los modos del escultor, y la parroquia donde se encuentra pertenece al área donde, presumiblemente, destinaría gran parte de su trabajo ${ }^{51}$.

Este San Juan Bautista completaría el exiguo catálogo que provisionalmente proponemos para Del Cid, conscientes de que en los próximos años saldrán a la luz nuevas obras suyas, muchas de ellas mal atribuidas o inéditas hasta la fecha. Sería interesante investigar la vinculación de nuestro artista con la zona de Talavera de la Reina, un lugar donde llama la atención el significativo número de encargos a escultores madrileños durante las décadas centrales del si-

dorada. Para las tallas madrileñas remitimos a los estudios de SAGÜÉs AzconA, Pío (O.F.M.): La Real Congregación de San Fermín de los Navarros en Madrid (1683-1961), Madrid, 1963, pp. 174-175 y 256; García GaínZA, María Concepción: Luis Salvador Carmona en San Fermín..., op. cit., pp. 65, fig. 20; PÉrez De Domingo, Lorenzo: "La obra del escultor Juan Pascual...", op. cit., pp. 286-289, fig. 1; El escultor Juan Pascual.., op. cit., pp. 168-169 y 183, figs. 60 y 71. Consideramos que la calidad de la talla de la parroquia de San Ginés es bastante inferior, en todos los órdenes, a la que se encontraba en San Fermín; es probable que se trate de una copia de taller.

${ }^{51}$ Curiosamente, en la misma parroquia se conserva una San José con el Niño que sigue muy de cerca el prototipo creado, una vez más, por Juan Pascual de Mena. Sería interesante indagar si su encargo guarda relación con el del San Juan Bautista, pues, indudablemente, parece del mismo periodo. 
glo XVIII. En la cercana villa de El Real de San Vicente, por ejemplo, encontramos un extraordinario conjunto de Luis Salvador Carmona, compuesto por las cuatro imágenes del retablo de la capilla de la Vera $\mathrm{Cruz}^{52}$. Y en Talavera de la Reina existe un importante número de piezas debidas al escultor de Nava del Rey ${ }^{53}$. También en aquella ciudad se conocen obras atribuidas a Juan Pascual de Mena, como las dos piezas citadas de las Madres Carmelitas; además, como ya hemos apuntado, tenemos sospechas de que algunas obras atribuidas hasta la fecha al escultor y académico toledano pudieran deberse a las gubias de Del Cid. Un escultor más, José de Zazo y Mayo (1720-1789), aparece íntimamente vinculado a la Sierra de San Vicente. Nacido en una de las villas que integran esta comarca, Nombela (Toledo), allí dejó algunas de sus obras conocidas, aun cuando ya ejercía su oficio en Madrid, donde estuvo en el taller de Manuel Virués (17001758); en Talavera de la Reina se conservan dos tallas documentadas de su mano ${ }^{54}$.

Por supuesto, sería necesario rastrear la actividad de nuestro artista en Madrid donde, por el momento, no se le conoce ningún trabajo.

La última noticia que tenemos de nuestro escultor es de 1779. Ese año Fernando del Cid interviene como intermediario entre el maestro arquitecto José Ochoa, comisionado por el cabildo de la iglesia parroquial de San Pedro en Mendigorría (Pamplona), y la Real Academia de San Fernando, para que esta última emitiese un informe sobre dos altares colaterales para la parroquia.

El año anterior, el arquitecto Miguel de Garnica, natural de Estella, había presentado los diseños para ambos retablos a la iglesia, que por entonces efectuaba una serie de reformas para el ornato interior del templo. También el pamplonés Juan Antonio Bescansa había ofrecido sus trazas. La parroquia, por su parte, encargó al arquitecto vizcaíno Santos Ángel de Ochandátegui la ejecución de la obra, así como el examen de ambas trazas. Ochandátegui, que tenía un juicio muy negativo sobre el arte navarro de aquel momento -donde imperaba el gusto rococó-, criticó duramente los diseños, realizando él mismo sus trazas alternativas a las ya presentadas. Los

\footnotetext{
52 Se sabe que el encargo fue realizado por don Pedro Muñoz Segundo, natural de El Real y residente en la Villa y Corte. Además, algunos familiares de Salvador Carmona estuvieron estrechamente vinculados a la vecina villa de Nombela, y a otros pueblos de la Sierra de San Vicente; vid. Nicolau CASTRO, Juan: "Un conjunto de esculturas de Luis Salvador Carmona en el pueblo toledano de El Real de San Vicente", Archivo Español de Arte, n. ${ }^{\circ} 197$ (1977), pp. 59-77; "Noticias sobre la familia de Luis Salvador Carmona y sobre el escultor José de Zazo y Mayo", Boletín del Seminario de Estudios de Arte y Arqueología, LI (1985), pp. 488-490; "Algunas noticias sobre el arte religioso en la Sierra de San Vicente", Boletín de la Sociedad de Amigos de la Sierra de San Vicente, n. 3 (1992), pp. 95-99; y MARTín GonZÁlez, Juan José: Luis Salvador Carmona..., op. cit., pp. 205-213.

Respecto a este último punto quisiéramos plantear la siguiente hipótesis. Francisco Salvador Carmona (h. 17321806), sobrino del célebre escultor, tras estudiar Teología en Salamanca arribó en Toledo, siendo párroco de San Salvador y obteniendo dos capellanías en la catedral. En 1767 se le otorgaron poderes para efectuar una inspección en la villa de El Real de San Vicente, como miembro del toledano Consejo de la Gobernación. Además, al ser doctor ejerció como profesor en la Universidad de Santa Catalina. Precisamente allí debió de coincidir con un ilustre serrano nacido en Hinojosa de San Vicente, don José Jiménez Sánchez (1742-1820). Éste debió de estudiar en Toledo, doctorándose en Derecho Canónico y pasando a formar parte del profesorado de la Universidad -al igual que Salvador Carmona-. Durante más de treinta años se dedicó a la docencia, llegando a ser Vicescolástico de la institución toledana; actividad que compaginó con una brillante carrera eclesiástica en la que alcanzó una canonjía en la catedral y que culminó con su ascenso al episcopado de Cartagena (Murcia) en 1806. En definitiva, cabe preguntarse si la presencia del presbítero Salvador Carmona -y la de otros familiares suyos- en la Sierra de San Vicente está ligada de algún modo a la importante figura de José Jiménez. Para este personaje véase SÁnchez Manzano, Esteban y SÁnchez Rivera, Jesús Ángel: José Jiménez Sánchez. Ilustre obispo de Cartagena-Murcia (1806-1820), Madrid, Parroquia de la Inmaculada Concepción-Hinojosa de San Vicente (Toledo), 2007.

53 Martín GonzÁlez, Juan José: Luis Salvador Carmona..., op. cit., pp. 213-216.

${ }^{54}$ Nicolau Castro, Juan: "Noticias sobre la familia de Luis Salvador Carmona...”, op. cit., pp. 490-494, lám. II; Escultura toledana..., op. cit., pp. 222-224, figs. 221-224; "Algunas noticias sobre el arte religioso...”, op. cit., pp. 99-102.
} 
maestros navarros se mostraron muy contrariados, e incluso Miguel de Garnica escribió contraatacando de modo abierto al vizcaíno y defendiéndose de sus críticas. Ante el cariz que adquirían los acontecimientos, el gobernador y oficial principal del Obispado de Pamplona, don Francisco Javier de Amigot, publicó una sentencia el 26 de junio de 1779 ordenando a la parroquia de San Pedro remitir todas las trazas a la Real Academia de San Fernando para que emitiese un juicio sobre el contencioso proyecto ${ }^{55}$. Para ello, la parroquia encargó al arquitecto José de Ochoa que se ocupara del asunto, y es entonces cuando Ochoa contacta con Fernando del Cid, que seguía siendo vecino de Madrid ${ }^{56}$.

Es probable que ambos se conocieran de alguna obra en la que participasen conjuntamente, tal vez en Madrid, pues el propio encargo y la correspondencia sugieren una relación de confianza. Tanto es así que Del Cid, en connivencia con su amigo, incluyó una cuarta traza del propio Ochoa en el expediente que entregó a la Academia para intentar obtener la adjudicación de la obra, en una jugada oportunista -y quizá también algo subrepticia-.

Los académicos se reunieron en Junta, celebrada el 5 de septiembre de 1779, y emitieron su dictamen al respecto, recogido por el secretario, don Antonio Ponz ${ }^{57}$. Éste escribió una carta con la respuesta a don José Martínez de Arizala siete días después. Y el día 24 del mismo mes saldría el correo con las trazas y la respuesta de vuelta, que llegó el 10 de octubre a Mendigorría. La Academia desechó los diseños de Garnica y de Bescansa, que calificó como "ideas monstruosas";

55 Al margen de las disputas surgidas entre Ochandátegui y los maestros navarros, la Academia ya había movido los hilos para ampliar su control y regular las Bellas Artes conforme al horizonte estético defendido por la institución. Así, en Junta Ordinaria de 7 de diciembre de 1777 se indicaba: "Leído el acuerdo de la precedente di cuenta de una carta que me dirigió el S(eñ)or Protector con fecha en S(a)n Lorenzo el Real de 23 de Noviembre último, y juntamente de un exemplar impreso de otra circular escrita de orden de $\mathrm{S}(\mathrm{u}) \mathrm{M}$ (agestad) por el mismo S(eñ)or Protector a los Señores Arzobispos, Obispos y demás Prelados eclesiásticos // del Reino. Asimismo de una copia de la carta que S(u) $\mathrm{E}(\mathrm{xce}) 1$ (encia) escribió al Gobernador del Consejo de cuyos documentos se había dado cuenta anteriormente en la Junta particular de 29 de Noviembre último, y se estendieron en el acuerdo de la misma. Se reducía a exhortar S(u) $\mathrm{M}$ (agestad) en la expresada carta circular a dichos prelados ecclesiásticos según la Academia le había expuesto, que en las obras de consideración y ornatos de las fábricas sagradas, consultasen para el acierto de ellas a esta R(ea)l Academia, remitiendo a la misma por mi mano los dibuxos de las obras que intentasen hacer para que, diciendo la Academia breve y gratuitamente los defectos que encontrase y los medios más adaptados para el acierto, se lograse éste en la execución de dichas obras. La carta al Governador del Consejo era para que éste mandase practicar lo mismo a los Magistrados Seculares del Reino.”; AASF, Juntas Ordinarias (1776-1785), sig. 84-3, fol. 68. Unos días después, en Junta General de 31 de diciembre de 1777, se remitió una "carta circular a los Prelados de las Órdenes Regulares, semejante a la que anteriormente había escrito a los Señores Arzobispos, Obispos (...) exhortándoles a que envíen al examen de esta Academia los dibuxos de // las obras de alguna importancia que intentasen hacer en sus distritos, todo con el fin piadoso del decoro de los templos y otras fábricas sagradas, y de promover el importante estudio de la Arquitectura"; AASF, Ibid., fols. 69 v.-70 r.

De este modo, "poniendo en execución las cartas circulares q(ue) de or(de)n de S(u) Mag(esta)d están espedidas a los Arzobispos, Obispos y Abades de sus Reynos pertenecientes al novilísimo Arte de Arquitectura”, don José Martínez de Arizala, cura beneficiado de la parroquia, escribe la correspondiente carta a la atención del secretario de la Academia, don Antonio Ponz, junto con las cuatro trazas, "para que de ellas se (e)lixan las que sean de aprovación en esa R(ea)1 Academia”; AASF, Altares (1770-1831), sig. 2-34-3, carta del 28 de agosto de 1779, sin foliar.

56 Noticias publicadas por AzANZA LÓPEZ, José Javier: Op. cit., pp. 149-165.

57 En el Acta de la Academia se lee: "Habiendo dado cuenta del acuerdo antecedente, leí una Carta de d(o)n José Martínez de Arizala, Beneficiado de Mendigurría, para que la Academia se sirviese decir, qual de quatro trazas que extuvieron expuestas sería más arreglada para la fábrica de su Yglesia; pero habiendo sido vistas y examinadas por los Señores Profesores, ninguna de ellas mereció la aprobación, por no estar arregladas a las buenas máximas de Arquitectura, y algunas de ellas ser enteramente monstruosas. Quedé en participárselo al interesado, para que no se expongan sus caudales sin la posible seguridad del acierto; la que consiguirá valiéndose de Profesor inteligente (...), [Firmado y rubricado] Antonio Ponz". Entre los académicos que acudieron se encontraba Juan Pascual de Mena; AASF, Juntas Ordinarias (1776-1785), sig. 84-3, fols. 133 v.-134 r. 
los otros fueron calificados como "más regulares" -aunque se prefería los de Ochandátegui-, y se aconsejó que se ejecutaran nuevas trazas por mano de algún arquitecto de la Corte, sin duda, un maestro afín a los ideales estéticos defendidos desde la institución ${ }^{58}$. Finalmente, el 17 de marzo del año siguiente el obispado pamplonés ordenaría que los retablos colaterales se hicieran según las trazas de Ochandátegui, y que se ejecutasen por el arquitecto Juan Antonio Bescansa uno y por el escultor Juan José de Echarri el otro, aunque Bescansa terminaría haciendo los dos por fallar Echarri.

El encargo de Ochoa a Del Cid indica que éste estuvo vinculado a la Real Academia de modo ocasional. No obstante, a través la carta que Del Cid envió al arquitecto podemos conocer la opinión crítica del escultor respecto a dicha institución:

"[las trazas] de Vmd. y Ochandátegui son las que tal qual dicen están mejores, pero no diciendo que se pueden hazer, pues ya sabe Vmd. las cosas de la Academia, pues si dan en que han de despreciar, aunque sea lo mejor lo desecharán" ${ }^{59}$.

Desde aquel lejano año de 1753 en que se presentó al Primer Premio de Escultura -cuyo fracaso, probablemente, le haría desistir de un segundo intento-, la actividad artística de nuestro escultor se había desarrollado en continuidad con la tradición del último Barroco, al menos por lo que hasta ahora conocemos; un arte alejado del nuevo espíritu neoclásico defendido desde la Academia. Leyendo entre líneas, las palabras de Del Cid acaso dejan entrever el sentimiento personal de quien no logró ningún reconocimiento en la institución, pero también la perplejidad de toda una generación de artistas que, continuadores de una tradición gremial inveterada y cultivadora del gusto rococó imperante, era menospreciada y atacada por un grupo elitista, el de los académicos, que abría las puertas a los aires renovadores del Neoclasicismo desde un nuevo sistema educativo y regulador de las Bellas Artes.

Quizá sea éste el motivo por el que ni Ceán en su Diccionario ni Ponz en su Viage de Espa$\tilde{n} a$ mencionen el nombre de nuestro escultor, como el de otros muchos contemporáneos. Sea como fuere, la obra de Fernando del Cid, de la que aún sabemos muy poco, queda justamente eclipsada por el arte de otros nombres más ilustres vinculados a la institución madrileña.

Fecha de recepción: 26-III-2008

Fecha de aceptación: 8-X-2008

58 José J. Azanza analiza el caso por extenso en su artículo, además de estudiar otros ejemplos referidos al ámbito navarro; AZANZA LóPEZ, José Javier: Op. cit.

59 Tomado de AzanZa López, José Javier: Ibid., p. 154. 